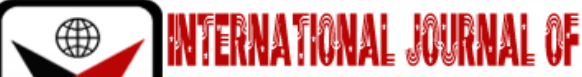

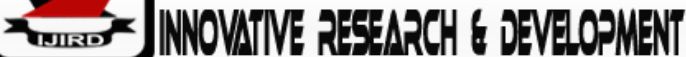

ISSN 2278-0211 (Online)

\section{Estimation of the Long-Run Relationship between Foreign Direct Investment and Economic Growth in Nigeria}

\begin{tabular}{c} 
Afolabi Olusesan Samuel \\
Lecturer, Department of Economics, \\
Joseph Ayo Babalola University, Ikeji Arakeji, Osun State, Nigeria \\
Jegede Abel Ilesanmi \\
Lecturer, Department of Economics, \\
Joseph Ayo Babalola University, Ikeji Arakeji, Osun State, Nigeria \\
\hline
\end{tabular}

\begin{abstract}
:
This study examines the long-run relationship between foreign direct investment and economic growth of Nigeria. The empirical results from this study show that the level of cumulative FDI has been rising since 1970, but cumulative FDI by activity has fluctuated up and down. The co-integration equation shows that a positive relationship exists between FDI, Labour (GNS), and real Gross Capital Formation in the long-run. The conclusion that emerged from the results was that FDI would be growth enhancing if inflow were greatly channeled to other productive sections of the economy such as manufacturing, agriculture, transport and communication.
\end{abstract}

Keywords: Estimation, relationship, foreign, investment, economic, growth

\section{Introduction}

Foreign Direct Investment (FDI) is defined as a long-term investment by a foreign direct investor in an enterprise resident in an economy other than the economy in which the foreign director investor is based (IMF, 2003). FDI may also be viewed as a form of international inter-firm co-operation that involves a significant equity stake in, or effective management control of foreign enterprises (De Mello Jnr, 2008).

The FDI relationship consists of a parent enterprise and foreign affiliate which together form a Trans National Corporation (TNC). In order to qualify as FDI, the investment must afford the parent enterprise control over its foreign affiliate. The United Nations (UN) defines control in this case as owning $10 \%$ or more of the ordinary shares or voting power of an incorporated firm or its equivalent for an unincorporated firm (UNCTAD, 2004).

According to Aremu (2000), liberalization policy has expanded effects on economic space where producers and investors could interact, thus prompting globalization in which the economic actors behave as if the entire world is a single market. One important economic consequence of globalization for developing countries, Nigeria inclusive, has been the massive and unprecedented inflow of foreign private capital during the last decades of the $20^{\text {th }}$ century.

Given the low level of income and low savings in many African countries, the savings-investment gap has widened and there is little hope of closing it without the active involvement of private sector - both domestic and foreign. Thus, in order to finance the investment gap, it has become imperative to attract foreign investment (Akinlo, 2001).

Central to the poor level of economic growth of the countries in sun-Saharan Africa is low level of investment. Attracting foreign investment is therefore central to a new thinking for its economic growth. Moreover, positive benefit in terms of increased outputs, trade and higher growth are the main elements justifying the urge to get the world economies globalized. This has precipitated the call on the developing economies, Nigeria inclusive, to open their economies for direct foreign investment.

FDI especially is expected to enhance growth by encouraging the incorporation of new inputs and foreign technologies in the production function of the recipient economy. Moreover, FDI is expected to augment the existing stock of knowledge in the recipient economy through labour training and skill acquisitions, on one hand, and through the introduction of alternative management practices and organizational arrangements on the other (De Mello, 2008)

\section{Conceptual Framework}

Foreign Direct Investment is conventionally defined as a form of international inter firm cooperation that involves significant equity stake and effective management decision power in, or ownership control of foreign enterprise (Akinlo, 2004). FDI is also considered to encompass other broader, heterogeneous non-equity forms of cooperation that involve the supply of tangible and intangible assets by foreign enterprises to domestic firms (De Mello, 2008). Foreign 
Direct Investment flows are positively related to world trade. This is consistent with the observation that foreign trade inflows have expanded more than world trade with globalization (UNCTAD, 2004).

Anyawa (2010), in his study investigated the factors determining Nigeria direct investment, he differentiated between short and long-run determinants, then estimated error-correction models for FDI in order to shed light on the underlying short-run dynamics of Nigeria's FDI flows. His analysis suggested that FDI in Nigeria should have a great deal of sensitivity to change in domestic output or market must aim at higher domestic output because it encourages FDI inflows, while lower domestic output discourages such inflows. He then argued that higher change in GDP increase FDI flows to Nigeria, therefore measures must be sustained to raise the Nation's economic growth.

Chete (2003) examined the determinants of FDI in Nigeria using an error-correction model. He found out that in the short-run, FDI is sensitive to the real growth and lending rates; the inflation rate, the level of public investment, and political instability. He therefore, suggested the need to moderate the rate of domestic inflation through the implementation of monetary and fiscal policies, and the need to ensure political stability.

Following the traditional literature in financial economics, assets are priced in the absence of distortions so that riskiest asset offers the higher rate of return. Although risk can be reduced to a minimum by appropriately diversifying portfolio (Ajayi 2003). He stressed further that among the fundamental determinants of international capital flows are factors such as the investment opportunities available in the global economy, the covariance between the expected return on various investment projects, and the preference of individuals for present and future consumption, as well as their attitude towards risk.

Young (2010), however observed that there is a major problem in measuring empirically the effect of the factors listed on capital flows. International capital markets may react to a shock in one country through a change in the price of the country's financial claim. Moreover, as the international financial system becomes more integrated and portfolios more diversified, assets price linkages are the outcome arbitrage between financial markets rather than the capital flows.

Golub (2002), stressed that industrial countries are highly integrated financially. This view is partly based on the observation that gross financial flows among industrial countries are very substantial. But the size of gross flow is often taken to be an imperfect indicator of the degree of financial autarky, they need not necessarily occur between strongly integrated financial markets.

Levine (2002) in his study explained the major factor affecting capital movement as a country's-specific-pull factors reflecting domestic opportunity and risk. As developing countries credit worthiness is restored, capital (bond and equity) flows are likely to become an increasingly prominent source of external finance. For instance, equity related capital flow could be very large and come in form of either FDI or portfolio investment in equities. FDI may be attracted by the opportunity to use local raw materials or employ a local labour force. Withaimson (2000) noted that although portfolio equity flows to developing countries have increased, they are expected to be extremely sensitive to a country's openness, particularly to rules concerning the repatriation of capital and income. Lim (2001) identified the right to repatriate dividends and capital as the most important factor in attracting significant foreign equity flows. Credit ratings and secondary market prices of sovereign debt, reflecting the opportunities and risk of investing in the country, are likely to be important determining capital flows. It is thus expected that as developing countries undertake macroeconomic and institutional reforms, international investors will gain confidence and be more willing to direct capital flows toward the new markets.

\section{Empirical Review}

Foreign Direct Investment (FDI) is often seen as an important catalyst for economic growth in the developing countries. FDI is an important vehicle of technology transfer from developed countries to developing countries.

There is conflicting evidence in the literature regarding the question as to how, and what extent, FDI affects economic growth. FDI may affect economic growth directly because it contributes to capital accumulation, and the transfer of new technologies to the recipient country. In addition, FDI enhance economic growth where the direct transfer of technology augments the stock of knowledge in the recipient country through labour training and skill acquisition, new management practices and organizational arrangements (De Mello, 2008).

Nevertheless, most studies generally indicate that the effect of FDI on growth depend on other factors such as the degree of complementarity and substitution between domestic investment and FDI, and other country - specific characteristics. Buckley et al (2002) argued that the extent to which FDI contributes to growth depends on the economic and social condition in the recipient country. Countries with high rate of savings, open trade regime and high technological levels would benefit from increased FDI to the economies.

Borensztein, Gregorio, and Lee (2004) examine the role of FDI in promoting economic growth using an endogenous growth model. They analyzed FDI flows from industrial countries to developing countries. Their results also show that FDI is an important vehicle of technology transfer, contributing more to economic growth than domestic investment. They make a case for a minimum threshold stock of human capital necessary to absorb foreign technologies efficiently.

Several other studies including Keke (2003), have analyzed the FDI-led economic growth hypothesis. He argued that FDI increase factor productivity because of better utilization of capacity and economies of scale. He also argued that FDI are likely to alleviate foreign-exchange constraints and thereby facilitate importation of better technologies and production methods. Grossman and Helpman (2009) argued that open-trade regimes go hand-in-hand with good investment climates, technology externalities, and learning effects.

In the context of Nigerian economy, Oyaide (2010) focused on the role of Direct Private Foreign Investment (DPFI) in the economic development of Nigeria. Using indexes of dependence and development as barometers of Nigeria 
economic performance, he concluded that DPFI caused economic growth. He, therefore, suggested that studies on the role of FDI in host countries should entail time series analysis of specific features. In line with this argument, Akpokodje (2008) examined the impact of foreign assistance on industrial output in Nigeria using time series data spanning $2001-2010$ period. The study found out that FDI contributed positively to industrial output of Nigeria. Specifically, the results indicated that both foreign assistance and FDI in industry influence industrial output, thus leading to economic growth.

Some studies have found that productivity growth was higher in foreign-owned firms with positive impact on domestic firms through innovation of foreign affiliates and diffusion of skills as employments move to domestically owned firms and that the multinational enterprises are active in sectors that use relatively high level of skilled workers (Hanson 2009). Some channels have been identified in empirical work through which FDI impacts growth. These are through boosting of host country export and through backward as well as forward linkages with affiliates to multinationals (Markusen and Venables, 2009).

However, as noted in many of these studies reviewed above, the productivity of foreign capital is dependent on initial conditions of host country. Borensztein et al (2014), noted that the twin roles of the introduction of advanced technology and the degree of absorptive capacity in the host country are major determinants of growth.

Conclusively, what the above reviewed empirical studies suggest is that the ways in which FDI affect growth depends on the economic and technological conditions of the host country. This means that FDI would have positive or negative impact on economic growth depending on the way it affects the level of productivity.

\section{Research Design}

In the FDI - growth equation, we specify an augmented Cobb-Douglas production function in which the externality (positive or negative effect) of FDI is incorporated.

The Cobb-Douglas production function is stated as:

$$
\mathrm{G}=\mathrm{A}\left(\mathrm{LK} \mathrm{K}_{\mathrm{p}} \mathrm{E}\right)=\mathrm{A} \mathrm{L}^{\alpha} \mathrm{K}_{\mathrm{p}} \beta \mathrm{E}^{1-\alpha-\beta} \text {...... }
$$

Where $G$ is the real output, $K_{p}$ is private capital stock, $L$ is labour and E represents externality generated by additions to the stock or flow of FDI. $\alpha$ and $\beta$ are the shares of domestic labour and private capital respectively, and A captures the efficiency of production. It is equally assumed that $\alpha$ and $\beta$ are less than one, but that there are diminishing returns to labour and capital inputs.

The externality, E, can be represented by a Cobb-Douglas function of the type:

$$
\begin{aligned}
& \mathrm{E}=\left(\mathrm{LK}_{\mathrm{p}} \mathrm{K}_{\mathrm{f}}^{\mathrm{v}}\right)^{\varphi} \ldots \ldots \ldots \ldots . . \\
& \mathrm{E}=\left(\mathrm{L}^{\varphi} \mathrm{K}_{\mathrm{p}} \varphi \mathrm{K}_{\mathrm{f}}^{\mathrm{v} \varphi}\right)^{1-\alpha-\beta} .
\end{aligned}
$$

Where $\mathrm{v}$ and $\varphi$ are, respectively, the marginal and the inter-temporal elasticities of substitution between private and foreign capital. We assume $\mathrm{v}>0$ so that a larger FDI generates a positive externality to the economy. If $\varphi>0$ inter temporality prevails and $\varphi<0$, additions to the stock or flow of FDI crowd out private capital over time and diminish the growth potentials of the host country (Borsworth and Collins, 2009; Ramirez, 2010).

Substituting equation 3 to 1 , we get:

$\mathrm{G}=\mathrm{AL}^{\alpha} \mathrm{K}_{\mathrm{p}}{ }^{\beta}\left(\left(\mathrm{L}^{\varphi} \mathrm{K}_{\mathrm{p}} \varphi \mathrm{K}_{\mathrm{f}}^{\mathrm{v} \varphi}\right)^{1-\alpha-\beta}\right.$

Collecting the like terms of equation 4 using the law of indices, we get equation 5 . That is:

$G=A L^{\alpha+\varphi(1-\alpha-\beta)} K_{p} \beta(1-\alpha-\beta) K_{f} v \varphi(1-\alpha-\beta)$

Taking the log and time derivative of equation 5 , we obtain:

$\mathrm{gG}=\mathrm{gA}+[\alpha+\varphi(1-\alpha-\beta)] \mathrm{gL}+[\beta+\varphi(1-\alpha-\beta)] \mathrm{gK}_{\mathrm{p}}+[\mathrm{v} \varphi(1-\alpha-\beta)] \mathrm{gK}_{\mathrm{f}} \ldots \ldots \ldots$

$\mathrm{g}_{\mathrm{i}}$ is the growth rate of $\mathrm{i}$ where $\mathrm{i}=\mathrm{G}, \mathrm{A}, \mathrm{L}, \mathrm{K}_{\mathrm{p}}$ and $\mathrm{K}_{\mathrm{f}}$. Thus equation (6) states that (given that $\mathrm{v}$ and $\varphi>0$ ) additions to the flow or stock of FDI will augment the elasticities of output with respect to labour and capital by a factor $\varphi(1-\alpha-\beta)$, and this will in turn cause economic growth.

From equation (6), the model to be estimated according to Mankiv, Romar, and Weit (1992) is:

$\Delta$ In $\mathrm{G}=\mathrm{d}_{\mathrm{o}}+\mathrm{d}_{1} \Delta \operatorname{In} \mathrm{K}_{\mathrm{f}}+\mathrm{d}_{2} \Delta \operatorname{In} \mathrm{K}_{\mathrm{p}}+\mathrm{d}_{3} \Delta$ In L

The model can be specified thus:

$G=\alpha_{0}+\alpha_{1} K_{f}+\alpha_{2} K_{p}+\alpha_{3} L+e$

This can be written thus:

$\mathrm{GDP}_{\mathrm{t}}=\alpha_{0}+\alpha_{1} \mathrm{FDI}_{\mathrm{t}}+\alpha_{2} \mathrm{GCF}_{\mathrm{t}}+\alpha_{3} \mathrm{GNS}_{\mathrm{t}}+\mathrm{e}_{\mathrm{t}}$

Where:

GDP = Gross Domestic Product

FDI = Foreign Direct Development

$\mathrm{GCF}=$ Gross Capital Formation

GNS = Graduates from Nigerian Schools

$\mathrm{e}=$ Stochastic Error Term

$\mathrm{t}=$ Time Subscripts

$\alpha_{0}, \alpha_{1}, \alpha_{2}$, and $\alpha_{3}=$ Parameters

The a-priori expectation on the parameter is stated as follows:

$\square \mathrm{GDP}>0 ; \square \mathrm{GDP}>0 ; \square \mathrm{GDP}>0$;

$\square \mathrm{GDP}>0 ; \square \mathrm{GDP}>0 ; \square \mathrm{GDP}>0$; 


\section{Technique for Data Analysis}

Following the objective of the paper, to estimate of the long-run relationship between Foreign Direct Investment and economic growth of Nigeria, the method of estimation technique adopted for this work is quantitative with reference to Error Correction Model (ECM).

Co-integration technique is an estimation technique which studies the long-run linear relationship among different variables or series. It is more reliable than ordinary regression method because it does not lead to spurious regression.

Co-integration is a property of two or more variables which have already shown to be integrated and which though trending (non-stationary) cannot drift too far apart since they are tied together in some sense, a long-run equilibrium will exist in a model based on such variables.

The co-integration technique, according to Engel and Granger (1987), has three major stages. The first stage involves studying the time series properties of the variables, that is, the level of stationarity. This is achieved through the conventional Unit Root test of non-stationarity. The second stage is necessary if the variables are found to be integrated of the same order, this is called the co-integration test and the last stage is the Error Correction Modeling (ECM). These stages are briefly reviewed below.

\subsection{Unit Root Test}

This is formal statistical test for non-stationarity in variables. A time series is said to be stationary if the following conditions hold:

(i). It has a constant mean independent of time i.e. $\mu_{\mathrm{xt}}=\mu_{\mathrm{x}}$

(ii) It has a constant variance independent of time i.e. $\square^{2}=\square^{2}$

(iii) Auto-covariance (and auto-correction) depends only upon the difference in the time index and not upon their location in time.

A non-stationary time series is one in which one or all of these above mentioned conditions do not hold. If a variable is non-stationary, it may either belong to the class of a pure random walk or random walk with drift with an error term referred to a "coloured noise". What I peculiar to random walk is that the auto-correlation is large and does not fade away with time, meaning that the variable has a persistent shock given any disturbance, the memory is sustained. This is one of the time series properties of non-stationary variable. A stationary variable has a limited memory given a shock. The shock fades away and disappear with time, such noise is said to be a "white noise".

The essence of studying the time series properties of variables before regression is to avoid spurious regression. A non-stationary variable can be made stationary by differencing a number of times. If a series is made stationary by firstdifferencing, it is said to be integrated of order one, denoted as I(1) and have a unit root. In general a series with I(d) is said to have $d$ unit roots.

A stationary series is thus integrated of order zero denoted as I(0). Most macro-economic variables have been identified to I(1), a few are I(0) and few are also integrated of order higher than 1 (Obadan 2004). The Augmented Dickey Fuller (ADF) test is used to test for the presence of a unit root in series.

\subsection{Error-Correction Model (ECM)}

If the two variables are found to co-integrate, that is, they exhibit a long-term equilibrium relationship, then there must exist an associated Error-Correction Model (ECM) according to Engel and Granger (1987). The ECM can be in form of an over parametrized or parsimonious (data reduction). The usual ECM may take the following form:

$$
\begin{aligned}
& \mathrm{T} \quad \mathrm{T} \\
& \Delta \mathrm{GDP}_{\mathrm{t}}=\lambda_{0} \mathrm{e}_{\mathrm{t}-1}+\Sigma \lambda \mathrm{j} \Delta \mathrm{FPI}_{\mathrm{t}-\mathrm{j}}+\Sigma \theta \mathrm{j} \Delta \mathrm{GDP}_{\mathrm{j}-\mathrm{I}}+\mathrm{V}_{\mathrm{t}} \\
& j=1 \quad j=1
\end{aligned}
$$

Where:

$\begin{array}{lll}\Delta & = & \text { First difference operator. } \\ \mathrm{e}_{\mathrm{t}-1} & = & \text { Error correction term. } \\ \mathrm{T} & = & \text { Number of lags necessary to obtain white noise. } \\ \mathrm{V}_{\mathrm{t}} & = & \text { Random disturbance term. } \\ \lambda & = & \text { Coefficient of ECM. }\end{array}$

The ECM describes the short-term dynamics or adjustment needed to achieve the long-run relationship between the two variables. $\lambda_{0}$ depicts the extent of disequilibrium between $\mathrm{GDP}_{\mathrm{t}}$ and $\mathrm{FDI}_{\mathrm{t}}$. if the absolute value of the coefficient of the ECM i.e. $/ \lambda /$ is significantly different from zero, then $\mathrm{GDP}_{t}$ and $\mathrm{FPI}_{t}$ will actually have a long-run relationship. Not only that, the ECM also includes flexibility by combining the short-run and long-run dynamics in a unified system. $\lambda \mathrm{j}$ and $\theta \mathrm{j}$ are parameters measuring the short-run dynamics of the $\mathrm{GDP}_{\mathrm{t}}$ with respect to $\mathrm{FDI}_{\mathrm{t}}$ and its own lag respectively.

\section{Discussion of Result}

\subsection{Trend Analysis}

Table 1 shows the level and trend of foreign direct investment in Nigeria. Table 1 indicates, the cumulative level of FDI rose from the level of 1,0032.2 million naira in 1970 to 3,260.1 million naira in 1980, while in 1990, 2000, and 2004, it increased to 10,436.1 million naira, 157,508.6 million naira and 249.639.3 million naira respectively. The trend of FDI as indicated above shows that cumulative foreign direct investment was very low in Nigeria between 1970 and 1985. 


\begin{tabular}{|c|c|c|c|c|c|c|c|c|c|}
\hline 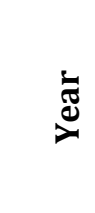 & 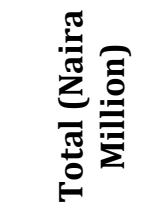 & 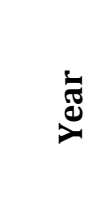 & 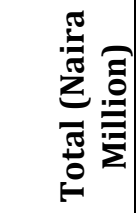 & ఫ্ঠ & 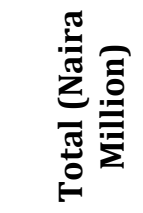 & 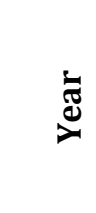 & 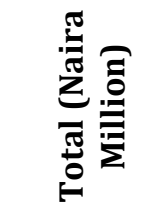 & 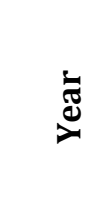 & 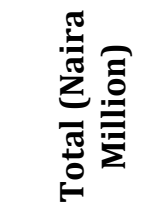 \\
\hline 1970 & 1003.2 & 1977 & 2531.4 & 1984 & 6418.3 & 1991 & 13664.4 & 1998 & 152410.9 \\
\hline 1971 & 1322.8 & 1978 & 2863.2 & 1985 & 6804.0 & 1992 & 20612.7 & 1999 & 154190.3 \\
\hline 1972 & 1571.1 & 1979 & 3153.1 & 1986 & 9313.6 & 1993 & 60787.0 & 2000 & 157508.6 \\
\hline 1973 & 1763.7 & 1980 & 3620.1 & 1987 & 9993.6 & 1994 & 70713.7 & 2001 & 161441.6 \\
\hline 1974 & 1812.1 & 1981 & 3757.9 & 1988 & 11339.2 & 1995 & 119391.6 & 2002 & 166631.6 \\
\hline 1975 & 2287.5 & 1982 & 5382.8 & 1989 & 10899.8 & 1996 & 126800.9 & 2003 & 179687.7 \\
\hline 1976 & 2339.0 & 1983 & 5949.5 & 1990 & 10436.1 & 1997 & 128331.9 & 2004 & 249639.3 \\
\hline
\end{tabular}

Table 1: Cumulative level of Foreign Direct Investment in Nigeria (1970- 2004)

Source: Central Bank of Nigeria - Statistical Bulletin (2004)

However, since 1986, the cumulative level of FDI in the Nigerian economy has been increasing. The increasing trend in the cumulative level of foreign direct investment in Nigeria since 1986 may be attributed to several factors which include liberalization of the capital market in Nigeria and the adoption of economic deregulation programmes in Nigeria.

\begin{tabular}{|c|c|c|c|c|c|c|c|}
\hline$\underset{\mathbb{Z}}{\stackrel{7}{二}}$ & 事 & 坣 & 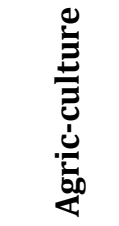 & 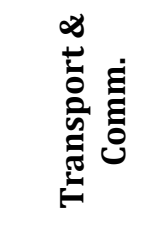 & 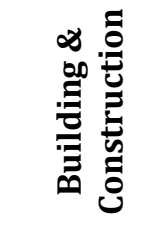 & 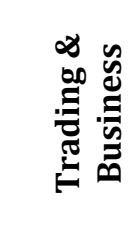 & 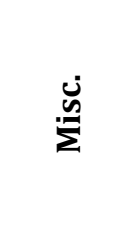 \\
\hline $1970-74$ & 762.5 & 377.9 & 12.9 & 14.3 & 34.5 & 250.5 & 41.9 \\
\hline $1975-79$ & 771.5 & 885.3 & 70.9 & 37.1 & 174.7 & 527.1 & 168.1 \\
\hline $1980-84$ & 678.3 & 1873.9 & 123.6 & 70.0 & 387.8 & 1568.3 & 323.9 \\
\hline 1985-89 & 1910.9 & 3450.8 & 127.0 & 112.1 & 478.4 & 3095.7 & 495.2 \\
\hline 1990-94 & 12497.1 & 10344.5 & 705.5 & 372.2 & 1080.0 & 1751.4 & 9672.0 \\
\hline 1995-99 & 58917.4 & 31913.3 & 1209.0 & 608.5 & 2612.3 & 6334.6 & 34490.2 \\
\hline 2000-04 & 61577.9 & 52756.4 & 1209.0 & 2136.7 & 4448.3 & 14046.9 & 46806.5 \\
\hline
\end{tabular}

Table 2: Average Level of Cumulative FDI by Activity in Nigeria (1970-2004)

Source: Computation from Central Bank of Nigeria's Statistical Bulletin (2004)

Between 1980-1984, the analysis of Table 2 also shows that the average level of cumulative FDI in mining and quarrying sector was 678.5 million naira, while the average cumulative FDI in manufacturing, trading and business sectors were 1873.9 million naira and 1568.3 million naira respectively. This pattern shows that the average cumulative FDI in the mining and quarrying sector has declined relative to that of manufacturing, trading and business sectors. During the period under review, 1985 to 1989, the average cumulative FDI in mining and quarrying, manufacturing and trading and business sectors stood at 1910.9 million naira, 3,450.8 million naira and 3,095.7 million naira respectively. This pattern was however reversed to the existing one between the period 1970 and 1974.

\section{Model Estimation Results}

\subsection{Unit Root Test for Data Series}

In an attempt to estimate the relationship between Foreign Direct Investment and the economic growth of Nigeria, this study initially examines the time series properties of data employed in the study. Testing the time-series properties of data is of crucial importance because studies have indicated that most economic series are non-stationary. To ascertain the time-series properties of data, this study tested for unit root in data by employing the Augmented Dickey Fuller Test. A data series is said to be of unit root [i.e., I (1)] when it becomes stationary after the first difference. When data are of unit root, application of ordinary least square regression technique, have been proved to yield spurious results.

When the Augmented Dickey Fuller Test was obtained, the result shows that all the series collected for the purpose of analysis were non-stationary in level. This is evidence from the fact that the null hypothesis that variables rgdp, fdi, rgcf, and gns are non-stationary cannot be rejected at the $5 \%$ level. This is evidenced from absolute values of ADF test statistics which are greater than their critical values at the $5 \%$ level. The implication of co-integration among variables which are I(1) series is that a long-run relationship exists among these variables. This also connotes that there is a comovement among these variables in the long-run.

\section{Conclusion}

This paper is devoted to explore the estimation of the long-run relationship between foreign direct investment and economic growth of Nigeria using co-integration framework. This study found out that the trend of FDI has been on 
the increase in Nigeria during the period under study. Moreover, over the short-run, the impact of FDI on growth has not been significant. However, despite the above findings, a long-run relationship is found to exist between FDI and growth in Nigeria.

One of the basic reasons for the insignificance of effect of FDI on growth in the short-run has been attributed to the concentration of the bulk of FDI on the oil sector in Nigeria. The implication of this is that FDI would be growth enhancing if inflow is greatly channeled to other productive sectors of the economy such as manufacturing, agriculture etc.

\section{Recommendations}

In light of the findings which emerged in this study, the following recommendations are made:

There is the need for the government of Nigeria to put in place measures that would promote the inflow of FDI in the country. These measures include among others the creation of conducive environment for international investment as well as enhancing the inflow of FDI by tax incentives.

Inflow of FDI into productive sectors such as agriculture, and manufacturing should be enhanced by wooing foreign investors to directly participate in these crucial sectors. The situation in |Nigeria is such that the oil sector has been the dominant sector receiving the bulk of FDI inflow. Therefore, increase in FDI inflow into other sectors would lead to economic growth in Nigeria.

Finally, the Federal Government should concentrate on the proper and efficient management of FDI in order to ensure that the country is not economically re-colonized. This will enhance economic growth rather than encouraging inflow of FDI into the country.

\section{References}

i. Ajayi S.I. (2003) - Nigeria and Political Economics of Development, The Dreams, The Myth and the Reality, Presidential Address to the $4^{\text {th }}$ Annual Conference of Nigeria Economic Society (NES).

ii. Akinlo A.E. (2001) - Foreign Direct Investment and Growth in Nigeria, An Empirical Investigation, Journal of Policy Modeling, North Holland. Pp 627-630.

iii. Akpokodje M. (2008) - Foreign Investment and Spillover Efficiency in a Developing Economy: World Development Journal 6 pp 47-49.

iv. Anyawa N.J. (2010) - The Determinants of FDI in Transforming Economies Journal of Development Studies Vol 30 no 6 pp 450-561.

v. Aremu J.A. (2000) - Foreign Private Investment; Issues, Determinant and Performance, Paper presented at a workshop on Foreign Investment Policy and Practice.

vi. Borensztein E.J. De Gregorio and Lee J. (2004) - How does FDI Affect Economic Growth, Journal of International Economics 45 (115-135).

vii. Buckley P.J., J. Clegg, and C. Wang (2002) - The impact of Inward FDI on the Performance of Chinese Manufacturing Firms, Journal of International Business Studies, 33 (4), 637-655.

viii. Chete L.N. (2003) - Determinant of Foreign Direct Investment in Nigeria, National Institute of Social and Economic Research (NISER), Monograph series No 7.

ix. De Mello L.R. (2008) - FDI in Developing Countries and Growth, A Selective Survey, Journal of Development Studies 34 (115-135).

x. Engle R. and Granger C. (1987) - Co-integration and Error Correction: Representation, Estimation and Testing Econometrical, Vol. 55, pp 251- 276.

xi. Golub M. (2002) - Money, Interest and Banking in Economic Development, Baltimore, MD: Jolins Hopkins University Press.

xii. Grossman G.M. and Helpman E (2009) - Innovation and Growth in the Global Economy, Cambridge, M.A; the MIT Press.

xiii. Hanson J.L. (2009) - A Textbook of Economics, Mac Donald and Evans Limited, London.

xiv. IMF (2003) - Foreign Direct Investment Statistics - How Countries Measure FDI, Washington D.C.

xv. Keke N. (2003) - Journal of Economics and Social Studies Vol 3, Department of Economics, University of Ado-Ekiti, Nigeria.

xvi. Levine R. (2002) - Financial Development and Economic Growth: View and Agenda Journal of Economic Literature, Vol 35, No 2. pp 60-75.

xvii. Lim D. (2001) - Fiscal Incentives and Direct Foreign Investment in LDCs, Journal of Development Studies 19 pp 207-210.

xviii. Markusen J.R. and Venables E.S. (2009) - Factor Movement and Commodity Trade as Complements, Journal of International Economics, 14 pp 341-356.

xix. Oyaide W.J (2010) - The Role of Direct Private Foreign Investment, Washington D.C. United Press of America.

xx. UNCTAD (2004) - World Investment Report, Washington D.C.

xxi. Withaimson R.S. (2000) - Foreign production and Exports in Manufacturing Industries, Review of Economics and Statistics, 63, pp 488-494

xxii. Young A (2010) - Substitution and Complementary in Endogenous Innovation, Quarterly Journal of Economics, 108 pp 775-807. 